УДК 351.741:336-049.5

DOI: 10.35340/2308-104X.2019.83-2-10

\section{ПРАВООХОРОННІ ОРГАНИ В СИСТЕМІ ЗАБЕЗПЕЧЕННЯ ФIНАНСОВО-ЕКОНОМІЧНОЇ БЕЗПЕКИ КРАЇНИ}

\section{МАРИНА А. С.,} кандидат економічних наук, доцент кафедри обліку, фінансів та економічної безпеки, PEBA O. B., кандидат економічних наук, доцент кафедри обліку, фінансів та економічної безпеки

\section{ШЕВЧЕНКО О.О.,}

слухач магістратури з державного управління, ДВНЗ «Донецький національний технічний університет» (м. Покровськ)

\section{LAW ENFORCEMENT AGENCIES IN THE SYSTEM OF ENSURING FINANCIAL AND ECONOMIC SAFETY OF THE COUNTRY}

\author{
MARYNA A., \\ Candidate of Economics Science, \\ Associate Professor of Accounting, \\ Finance and Economic Security \\ Department, \\ REVA O., \\ Candidate of Economics Science, \\ Associate Professor of Accounting, \\ Finance and Economic Security \\ Department, \\ SHEVCHENKO O., \\ Master's degree studentat of the \\ State Administration, Donetsk \\ National Technical University \\ (Pokrovsk)
}

В роботі проведено дослідження складових національної безпеки, визначено місие фінансово-економічної безпеки в системі забезпечення захисту національних інтересів. Встановлено, що ефективне забезпечення економічної безпеки досягається за рахунок дотримання законодавства в сфері фінансово-господарської діяльності, щуо обумовлює важливість вивчення місия правоохоронних органів в системі забезпечення фінансово-економічної безпеки держави.

Ключові слова: начіональна безпека, економічна безпека, національні інтереси, правоохоронні органи, дотримання законодавства.

В работе проведено исследование составляюших национальной безопасности, определено место финансово-экономической безопасности в системе обеспечения защиты национальных интересов. Установлено, что эффрективное обеспечение экономической безопасности достигается за счет соблюдения законодательства в сфере финансово-хозяйственной деятельности, что обуславливает важность изучения места правоохранительных органов в системе обеспечения финансово-экономической безопасности государства.

Ключевые слова: начиональная безопасность, экономическая безопасность, национальные интересы, правоохранительные органы, соблюдение законодательства. 
In work the research of components of national security is conducted, the place of financial and economic safety in the system of ensuring protection of national interests is defined. It is established that effective ensuring economic security is reached due to compliance with the law in the sphere of financial and economic activity that causes importance of studying of the place of law enforcement agencies in the system of ensuring financial and economic safety of the state.

Keywords: national security, economic security, national interests, law enforcement agencies, compliance with the law.

Постановка проблеми. Економічна безпека на всіх рівнях забезпечується системою заходів дотримання законодавства в сфері фінансово-господарської діяльності. Реформування економічної, політичної та сфери державного управління, в деяких випадках навіть кардинальне, супроводжується криміналізацією суспільства та зростанням рівня злочинності в економічній та фінансовій сферах - що виступає істотною загрозою національній безпеці країни.

На сьогодні низький рівень економічної безпеки обумовлений також високим ступенем тінізації вітчизняної економіки (поширення неофіційної зайнятості, нелегальна трудова міграція, ухилення від оподаткування, ведення «чорного» бухгалтерського й податкового обліку, криміналізація економічних відносин тощо). Тіньова економіка є реальною загрозою національній безпеці України та демократичному розвитку, вона негативно впливає на всі сфери суспільного життя (економіку, політику, громадську свідомість, міжнародні відносини тощо).

Аналіз останніх досліджень $і$ публікаџій. Особливості організації системи правоохоронних органів та їх функцій в системі забезпечення фінансовоекономічної безпеки розглядаються в працях Бандурки О. М., Користіна О. Є., Білодіда І. М., Куліша А. М., Убілави Д. Р., Юртаєвої К. В. та інших.

Формулювання мети статті. Метою роботи є дослідження ролі, функцій та завдань правоохоронних органів України в системі забезпечення економічної безпеки держави.

Виклад основного матеріалу. Забезпечення захищеності національних інтересів держави (державного суверенітету, конституційного устрою, недопущення втручання до внутрішнього устрою тощо) від реальних й потенційних загроз та факторів дестабілізаційного впливу є основним завданням національної безпеки.

Питання захищеності національних інтересів $\epsilon$ предметом уваги як провідних країн світу, так i країн що розвиваються. Втім, кожна країна самостійно визначає перелік напрямів (сфер, інтересів), які включаються до складу національної безпеки, склад та структуру системи іiі забезпечення, суб'єктів та механізми відповідно до мети та завдань держави, ії можливостей в національній та міжнародній сферах.

Реалізовувати державну політику в сфері національної безпеки має сектор державної безпеки й оборони (рис. 1), який включає оборонно-промисловий комплекс, сили безпеки, сили оборони, а також громадян й громадські об'єднання, які за власним бажанням приймають участь у забезпеченні 
національної безпеки. Відповідно до [9] сектор безпеки і оброни являє собою певну систему органів державної влади, Збройних Сил України, правоохоронних та інших державних органів спеціального призначення 3 правоохоронними функціями, сил цивільного захисту, діяльність яких спрямована на захист національних інтересів держави. Функціонування сектору безпеки та оборони $\epsilon$ об'єктом демократичного цивільного контролю - комплексу заходів правового, організаційного, інформаційного, кадрового спрямування щодо забезпечення верховенства права, прозорості, підзвітності органів сектору безпеки і оборони при забезпеченні захисту національних інтересів держави та підвищенні ефективності їх діяльності.

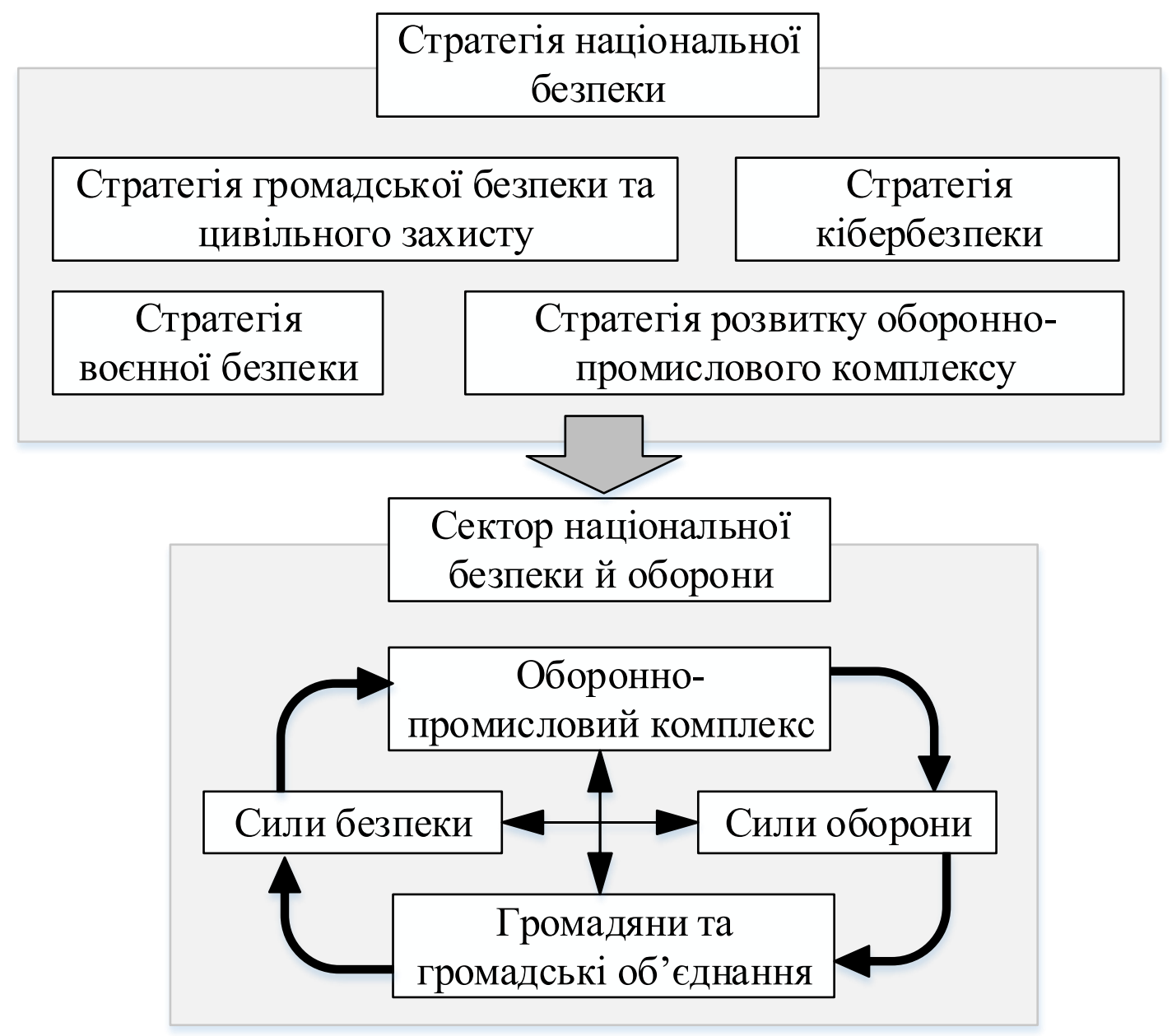

Рис. 1. Основні складові національної безпеки України

Складено за $[9,11]$

Таким чином, забезпечення захищеності національних інтересів реалізується наступними напрямами державної політики (рис. 2): забезпечення відновлення територіальної цілісності держави; формування ефективного сектору безпеки та оборони; підвищення обороноздатності держави; реформування та розвиток розвідувальних, контррозвідувальних i 
правоохоронних органів; реформування системи державного управління, нова якість антикорупційної політики; інтеграція в Європейський Союз; особливе партнерство з НАТО; забезпечення національної безпеки у зовнішньополітичній сфері; забезпечення економічної безпеки; забезпечення енергетичної безпеки; забезпечення інформаційної безпеки; забезпечення кібербезпеки i безпеки інформаційних ресурсів; забезпечення безпеки критичної інфраструктури; забезпечення екологічної безпеки.

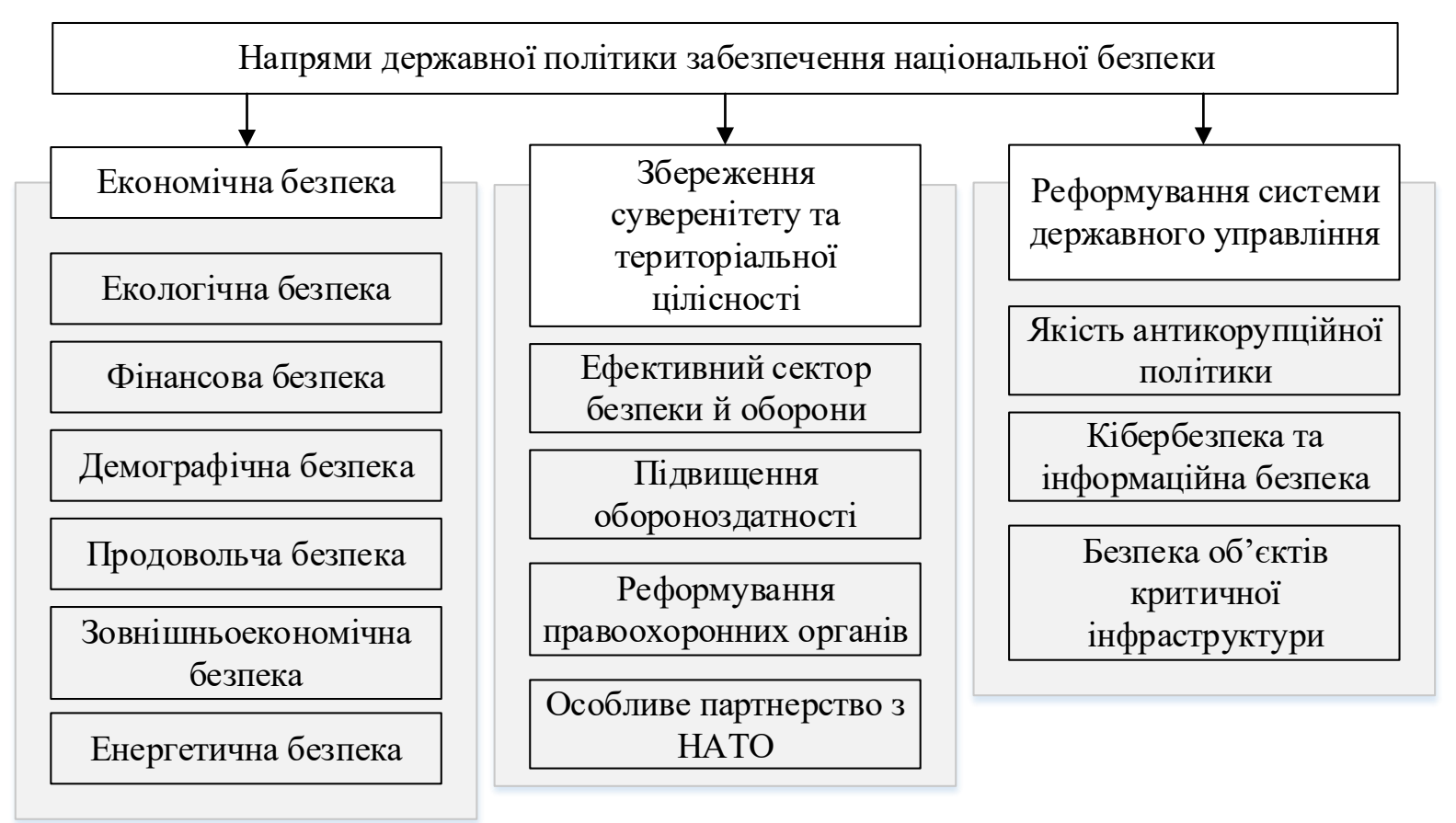

Рис. 2. Напрями державної політики при забезпеченні національної безпеки України Складено автором за [9, 11]

Внаслідок багатоаспектності та всеохоплюючому значенню національної безпеки для кожної країни, виникає необхідність в формуванні спеціальної системи іiі забезпечення. Система забезпечення національної безпеки являє собою певну сукупність об'єктів, механізмів, методів й інструментів захисту національних інтересів, цінностей, свобод в усіх сферах життєдіяльності держави та суспільства.

Серед усіх складових системи національної безпеки, економічна безпека займає особливе значення, тому що виступає матеріальною основою забезпечення захисту національних інтересів. По-різному трактуючи значення та сутність економічної безпеки, майже всі дотримуються позиції щодо іiі пріоритетності в державній політиці, важливого значення в умовах трансформаційних та глобалізаційних процесів.

Відповідно до [5], функціональне навантаження економічної безпеки полягає в визначенні реальних фінансових можливостей забезпечення інших складових національної безпеки, виступає певним підгрунтям для функціонування інших елементів системи забезпечення національної безпеки. 
Актуальність економічної безпеки обумовлюється також зростанням ролі та значення правоохоронної діяльності. Тінізація економіки, зростання іiі криміналізації, корумпованість влади, лобіювання інтересів окремих груп при ухваленні державних рішень, зокрема й в сфері забезпечення національних інтересів - те незначне коло перешкод розроблення й реалізації якісної стратегії економічної безпеки країни.

В дослідженні [1] йдеться про тісний взаємозв'язок між рівнем тіньової економіки та криміналізацією суспільства. Автор наголошує на тому, що поняття «криміналізація» і «тінізація економіки» тісно пов'язані між собою: тіньовий сектор $є$ наслідком криміналізації економіки та суспільства в цілому, і в той же час - однією з причин цього процесу та його каталізатором. А серед негативних наслідків означених процесів - втрата державою своїх регулюючих та контролюючих функцій. Крім того, сучасні злочини в економічній сфері значно відрізняються за складністю та «інтелектуальністю» та мають свої характерні риси:

вони охоплюють різноманітні зловживання економічної влади на різних рівнях управління, які зазіхають на порядок ведення економічного управління;

здійснюються у процесі професійної діяльності;

завдають значних економічних збитків інтересам держави, підприємницьких структур та населення.

Захист законних економічних інтересів особи, підприємства, суспільства i держави від таких загроз є завданням, насамперед, правоохоронних органів i спецслужб. Законом України «Про державний захист суддів, працівників апарату суду і працівників правоохоронних органів» [6] до правоохоронних органів, віднесено: органи прокуратури, внутрішніх справ, служби безпеки, Військової служби правопорядку у Збройних Силах України, органи охорони державного кордону, органи доходів і зборів, органи i установи виконання покарань, слідчі ізолятори, органи державного фінансового контролю, рибоохорони, державної лісової охорони, інші органи, які здійснюють правозастосовні або правоохоронні функції.

Розподіл функцій органів державного управління в процесі забезпечення захисту економічних інтересів наведено в (табл. 1.). Слід зазначити, що в Україні наразі фактично відсутній єдиний орган, який функціонально концентрував би в собі забезпечення національної безпеки та такої його найважливішої складової, як економічна безпека. Функції координації та контролю за діяльністю органів влади щодо забезпечення економічної безпеки держави покладено на Раду національної безпеки i оборони України, у складі якої утворено й діє Департамент економічної та соціальної безпеки [2]. А відповідно до ст. 17 Конституції України [3] обов'язки щодо захисту економічної безпеки держави покладаються на всі органи державної влади та органи місцевого самоврядування, підприємства, установи та організації, на усіх громадян України та їх об’єднання. 
Таблиця 1

Функції суб’єктів державного управління в забезпеченні економічної безпеки

\begin{tabular}{|c|c|}
\hline $\begin{array}{l}\text { Суб'єкт державної } \\
\text { системи - суб'єкт } \\
\text { забезпечення ФЕБ }\end{array}$ & $\begin{array}{c}\text { Функції у сфері забезпечення фінансово-економічної безпеки } \\
\text { країни }\end{array}$ \\
\hline $\begin{array}{l}\text { Верховна рада } \\
\text { України }\end{array}$ & $\begin{array}{l}\text { Орган законодавчої влади, який визначає основи економічної } \\
\text { безпеки, формує законодавчу базу в цій сфері }\end{array}$ \\
\hline Президент України & $\begin{array}{l}\text { Гарант державного суверенітету, додержання Конституції, прав } \\
\text { і свобод громадян; гарант забезпечення економічної безпеки } \\
\text { України, здійснює загальне керівництво у сфері національної } \\
\text { безпеки }\end{array}$ \\
\hline $\begin{array}{l}\text { Рада національної } \\
\text { безпеки України }\end{array}$ & $\begin{array}{l}\text { Координаційний орган з питань з питань національної (у тому } \\
\text { числі економічної) безпеки, який планує, організовує та } \\
\text { контролює здійснення заходів щодо забезпечення нейтралізації } \\
\text { загроз економічній безпеці держави }\end{array}$ \\
\hline $\begin{array}{l}\text { Кабінет міністрів } \\
\text { України }\end{array}$ & $\begin{array}{l}\text { Забезпечення державного суверенітету, економічної } \\
\text { самостійності та економічної безпеки }\end{array}$ \\
\hline $\begin{array}{l}\text { Міністерство } \\
\text { економічного } \\
\text { розвитку і торгівлі } \\
\text { України }\end{array}$ & $\begin{array}{l}\text { Здійснення державної політики в сфері економічного розвитку і } \\
\text { торгівлі, виконання заходів щодо забезпечення економічної } \\
\text { безпеки на макро-, мезо- та мікрорівнях }\end{array}$ \\
\hline $\begin{array}{l}\text { Інші центральні } \\
\text { органи виконавчої } \\
\text { влади }\end{array}$ & $\begin{array}{l}\text { Забезпечення виконання в межах своїх повноважень заходів } \\
\text { щодо мінімізації та нейтралізації загроз економічній безпеці } \\
\text { держави }\end{array}$ \\
\hline $\begin{array}{l}\text { Національний банк } \\
\text { України }\end{array}$ & $\begin{array}{l}\text { Визначає та проводить грошово-кредитну політику в інтересах } \\
\text { економічної безпеки України }\end{array}$ \\
\hline $\begin{array}{l}\text { Служба безпеки } \\
\text { України }\end{array}$ & $\begin{array}{l}\text { Забезпечення захисту державного } \\
\text { конституційного ладу, територіальної цілісності, економічного, } \\
\text { науково-технічного й оборонного потенціалу України }\end{array}$ \\
\hline $\begin{array}{l}\text { Суди загальної } \\
\text { юрисдикції }\end{array}$ & $\begin{array}{l}\text { Здійснення судочинства у справах про злочини, що завдають } \\
\text { шкоди економічній безпеці України; забезпечення судового } \\
\text { захисту суб'єктів економічної безпеки при порушенні їх прав в } \\
\text { процесі діяльності щодо забезпечення економічної безпеки }\end{array}$ \\
\hline $\begin{array}{l}\text { Органи прокуратури } \\
\text { України }\end{array}$ & $\begin{array}{l}\text { Здійснення нагляду за дотриманням законодавства в сфері } \\
\text { забезпечення фінансово-економічної безпеки }\end{array}$ \\
\hline $\begin{array}{l}\text { Державна } \\
\text { прикордонна служба }\end{array}$ & $\begin{array}{l}\text { Забезпечення недоторканності державного кордону та охорони } \\
\text { суверенних прав України в іï прилеглій зоні та виключній } \\
\text { (морській) економічній зоні. }\end{array}$ \\
\hline Національна поліція & $\begin{array}{l}\text { охорони прав і свобод людини, а також інтересів суспільства і } \\
\text { держави, надання в межах, визначених законом, послуг } 3 \\
\text { допомоги особам, які } 3 \text { особистих, економічних, соціальних } \\
\text { причин або внаслідок надзвичайних ситуацій потребують такої } \\
\text { допомоги }\end{array}$ \\
\hline
\end{tabular}


Продовження табл. 1

\begin{tabular}{|c|c|}
\hline $\begin{array}{l}\text { Державна фіскальна } \\
\text { служба України }\end{array}$ & $\begin{array}{l}\text { здійснює контроль за дотриманням податкового і митного } \\
\text { законодавства, законодавства щодо трансфертного } \\
\text { ціноутворення, законодавства щодо адміністрування єдиного } \\
\text { внеску та іншого законодавства, контроль за дотриманням } \\
\text { якого законом покладено на ДФС }\end{array}$ \\
\hline $\begin{array}{l}\text { Місцеві державні } \\
\text { адміністрації та } \\
\text { органи місцевого } \\
\text { самоврядування }\end{array}$ & $\begin{array}{l}\text { Виконання програм державного розвитку та забезпечення } \\
\text { економічної безпеки }\end{array}$ \\
\hline
\end{tabular}

Складено на основі $[2,6,7,8,10]$

Правоохоронні органи утворюють певним чином відособлену за ознакою професійної діяльності самостійну групу органів держави, що мають чітко визначені завдання та виконують певні правоохоронні функції. Мета, завдання та функції правоохоронних органів у цілому полягають у забезпеченні законності та правопорядку в усіх сферах життєдіяльності держави.

Щодо забезпечення економічної безпеки, то діяльність правоохоронних органів у цій сфері здебільшого зводиться до боротьби 3 економічною злочинністю - запобігання та викриття правопорушень у всіх галузях економіки України [1].

Високий рівень економічної злочинності загрожує не тільки економічній, а й національній безпеці та існуванню суспільства. В Україні серед економічних злочинів близько $40 \%$ - посягання у сфері службової діяльності, ще $30 \%$ злочини проти власності і 20\% припадає на сферу господарської діяльності [4]. До основних причин зростання злочинів в економічній сфері слід, насамперед, віднести соціально-економічну та політичну кризи в країні.

Протидіють економічній злочинності структурні підрозділи правоохоронних органів, на які законодавством покладено здійснення функцій у певній сфері. Зокрема це підрозділи Міністерства внутрішніх справ України, Державної податкової адміністрації України, Служби безпеки України та Державної митної служби України. Зазначені структури мають право збирати, накопичувати і зберігати інформацію щодо протиправної діяльності у сфері економіки та про осіб, які до неї причетні.

Користін О.Є. [4] виділяє три основні напрямки діяльності правоохоронних органів в процесі боротьби із злочинністю взагалі та 3 економічною злочинністю зокрема: загальна організація, профілактика злочинності, правоохоронна діяльність.

Правоохоронна діяльність в системі забезпечення економічної безпеки країни являє собою певний вид державної діяльності, яка здійснюється спеціальними повноваженими органами державної влади та спрямована на забезпечення законності, правопорядку, захисту прав та інтересів індивіда, суб'єкта господарювання та держави в економічній сфері. Така діяльність реалізується застосуванням заходів державного примусу і громадського впливу, у суворій відповідності із законом та при дотриманні встановленої для них процедури (порядку), з притягненням винних до юридичної відповідальності. 
Функції окремо взятого підрозділу правоохоронного органу, що здійснює боротьбу 3 економічною злочинністю, наводяться та конкретизуються у відповідних нормативно-правових актах. До основних напрямів діяльності правоохоронних органів, що випливають із загальної політики держави в сфері протидії та боротьби з економічною злочинністю $є$ [4]:

використання комплексу оперативно-розшукових заходів для запобігання економічним злочинам, їх викриття та припинення;

протидія незаконній підприємницькій та іншій господарській діяльності юридичних та фізичних осіб;

виявлення економічних злочинів та проведення щодо них дослідчої (попередньої) перевірки;

захист від вчинення злочинів у бюджетній сфері;

виявлення та притягнення до відповідальності осіб, які скоїли економічний злочин;

вжиття заходів щодо забезпечення відшкодування державі юридичним та фізичним особам збитків, завданих унаслідок скоєння економічних злочинів;

інформаційно-аналітичне забезпечення боротьби 3 економічною злочинністю.

Серед напрямів забезпечення належного рівня економічної безпеки та скорочення економічної злочинності загалом можливе визначити:

ухвалення нових законів, правових актів, спрямованих проти економічної злочинності;

подальше удосконалення системи та принципів діяльності правоохоронних органів, які зобов'язані протидіяти економічній злочинності, 3 більш чітким розмежуванням їхніх повноважень і компетенції;

встановлення принципових, вихідних положень щодо структури та організації діяльності правоохоронних органів, спрямованих на профілактику економічної злочинності;

поєднання зусиль правоохоронних органів під час виконанню покладених на них функцій у боротьбі з економічною злочинністю через покращання координації їніх дій;

визначення нових юридичних та науково-технічних засобів методів i прийомів протидії економічній злочинності;

посилення обов'язку щодо сприяння правоохоронним органам у боротьбі 3 економічною злочинністю державних органів, державних, громадських, приватних організацій, а також населення із встановленням меж їхньої участі у цій діяльності;

розвитку фінансової і матеріально-технічної бази для діяльності правоохоронних органів при протидії економічній злочинності.

В сучасних умовах протидія злочинності здійснюється правоохоронними органами за трьома напрямами. Перш за все, це використання превентивного та виховного впливу кримінального законодавства; застосування кримінальноправових заходів; а також спеціальне кримінологічне запобігання злочинності (профілактичного запобігання реально можливим злочинам i припинення розпочатої діяльності). Використовувані на сьогодні правоохоронними органами заходи щодо боротьби зі злочинністю та іншими правопорушеннями в 
економічній сфері умовно можна поділити на загальні та спеціальні. До загальних заходів протидії злочинності та інших правопорушень належать підвищення добробуту населення, зростання його культурного рівня, підвищення освіченості, інші заходи соціального характеру. Спеціальні заходи ті, що прямо і безпосередньо впливають на злочинність та інші правопорушення. Саме вони пов'язані з діяльністю правоохоронних органів та реалізуються в процесі боротьби з економічними правопорушеннями.

Висновки та перспективи подальших досліджень. Правоохоронні органи займають вагоме місце в системі забезпечення фінансово-економічної діяльності країни, оскільки їх діяльність спрямована як на захист національних, суспільних та особистісних інтересів так і на контроль за дотриманням законодавства в процесі забезпечення фінансово-економічної безпеки. Перспективними напрямами подальших досліджень $\epsilon$ вивчення превентивних заходів в правоохоронних органів в системі забезпечення фінансово-економічної безпеки, зокрема зменшення рівня економічної злочинності та тінізації національної економіки.

\section{Лimepamypa:}

1. Бандурка О. М. Роль правоохоронних органів у зміцненні безпеки фінансової системи держави. Актуальні питання безпеки фінансової системи держави. Харків, 2016. С.15-19.

2. Гбур 3. В. Основні функції держави у сфері забезпечення економічної безпеки. Актуальні проблеми державного управління. 2017. №2(52). - C. $43-47$.

3. Конституція України. Закон України від 28.06.1996 № 254к/96-ВР. URL: https://zakon.rada.gov.ua/laws/show/254к/96-вр (дата звернення 24.02.2019 p.)

4. Користін O. Є. Економічна безпека. URL: https://pidruchniki.com/ 1584072021588/ekonomika/ekonomichna_bezpeka (дата звернення 24.02.2019 р.)

5. Малишко В. М. Актуальні проблеми економічної безпеки в системі національної безпеки України. Юридичний вісник. Повітряне і космічне право. 2015. № 4. C. 129-133.

6. Про державний захист суддів, працівників апарату суду i працівників правоохоронних органів. Закон України від 23.12.1993 (із змінами та доповненнями) № 3781-XII. URL: http://zakon.rada.gov.ua/laws/show/3781-12 (дата звернення 24.02.2019 р.)

7. Про Державну прикордонну службу України Закон України від 03.04.2003 № 661-IV (зі змінами та доповненнями). URL: https://zakon.rada.gov.ua/laws/show/661-15 (дата звернення 20.03.2019)

8. Про Державну фіскальну службу України. Постанова Кабінету міністрів України від 21.05.2014 №236 (зі змінами та доповненнями). URL: https://zakon.rada.gov.ua/laws/show/236-2014-\%D0\%BF (дата звернення 20.03.2019)

9. Про національну безпеку України. Закон України від 21.06.2018 №2469-VIII. URL:https://zakon.rada.gov.ua/laws/show/2469-19 (дата звернення 24.02.2019 p.) 
10. Про національну поліцію. Закон України від 01.01.2019 №580-VIII. URL: https://zakon.rada.gov.ua/laws/show/580-19 (дата звернення 20.03.2019)

11. Про рішення Ради національної безпеки і оборони України від 6 травня 2015 року «Про Стратегію національної безпеки України». Указ Президента України від 26.05.2015 р. № 287/2015 URL:https://zakon.rada.gov.ua/ laws/show/287/2015 (дата звернення 24.02.2019 р.)

References:

1. O. M. Bandurka, (2016) "Rol pravookhoronnykh orhaniv u zmitsnenni bezpeky finansovoi systemy derzhavy", Aktualni pytannia bezpeky finansovoi systemy derzhavy. Kharkiv, pp. 15-19.

2. Z. V. Hbur, (2017) "Osnovni funktsii derzhavy u sferi zabezpechennia ekonomichnoi bezpeky",Aktualni problemy derzhavnoho upravlinnia, no 2(52), pp. 43-47.

3. Konstytutsiia Ukrainy, Zakon Ukrainy vid 28.06.1996 № 254k/96-VR, available at: https://zakon.rada.gov.ua/laws/show/254k/96-vr (data zvernennia 24.02.2019 r.)

4. O. Ye. Korystin, "Ekonomichna bezpeka", available at: https://pidruchniki.com/1584072021588/ekonomika/ekonomichna_bezpeka.

5. V. M. Malyshko, (2015) "Aktualni problemy ekonomichnoi bezpeky v systemi natsionalnoi bezpeky Ukrainy", Yurydychnyi visnyk. Povitriane i kosmichne pravo, no 4, pp. 129-133.

6. Pro derzhavnyi zakhyst suddiv, pratsivnykiv aparatu sudu i pratsivnykiv pravookhoronnykh orhaniv, Zakon Ukrainy vid 23.12.1993 (iz zminamy ta dopovnenniamy) № 3781-KhII. available at: http://zakon.rada.gov.ua/laws/show/378112 (data zvernennia 24.02.2019 r.)

7. Pro Derzhavnu prykordonnu sluzhbu Ukrainy Zakon Ukrainy vid 03.04.2003 № 661-IV (zi zminamy ta dopovnenniamy). available at: https://zakon.rada.gov.ua/laws/show/661-15 (data zvernennia 20.03.2019 r.)

8. Pro Derzhavnu fiskalnu sluzhbu Ukrainy. Postanova Kabinetu ministriv Ukrainy vid 21.05.2014 №236 (zi zminamy ta dopovnenniamy). available at: https://zakon.rada.gov.ua/laws/show/236-2014-\%D0\%BF.

9. Pro natsionalnu bezpeku Ukrainy. Zakon Ukrainy vid 21.06.2018 №2469VIII. available at:https://zakon.rada.gov.ua/laws/show/2469-19 (data zvernennia 24.02.2019 r.)

10. Pro natsionalnu politsiiu. Zakon Ukrainy vid 01.01.2019 №580-VIII. available at: https://zakon.rada.gov.ua/laws/show/580-19 (data zvernennia 20.03.2019 r.)

11. Pro rishennia Rady natsionalnoi bezpeky i oborony Ukrainy vid 6 travnia 2015 roku «Pro Stratehiiu natsionalnoi bezpeky Ukrainy». Ukaz Prezydenta Ukrainy vid 26.05.2015 r. № 287/2015 available at:https://zakon.rada.gov.ua/laws/show/ 287/2015 (data zvernennia 24.02.2019 r.)

Economic security at all levels is ensured by the system of measures of compliance with the law in the sphere of financial and economic activity. Reforming 
economic, political and spheres of public administration, in certain cases even cardinal, is followed by criminalization of society and growth of crime rate in economic and financial spheres - that acts as significant threat of national security of the country. Nowadays the low level of economic security is caused by also high degree of a shadow of domestic economy (distribution of informal employment, illegal labor migration, evasion from taxation, conducting "black" business and tax accounting, criminalization of the economic relations). The shadow economy is real threat of national security of Ukraine and democratic development, it has negative effect on all spheres of public life (economy, policy, public consciousness, the international relations, etc.).

The question of security of national interests is a subject of attention both the leading countries of the world, and developing countries. However, each country independently defines the list of the directions (spheres, interests) which are included national security, structure and structure of a system of its providing, subjects and mechanisms according to the purposes and problems of the state, its opportunities in national and international spheres.

To realize state policy in the sphere of national security has the sector of state security and defense which includes defense industry complex, security forces, defense forces and also citizens and public associations, at own will take part in ensuring national security.

Owing to a lot of aspects and to complex value of national security for each country, there is a need for formation of a special system of its providing. The system of ensuring national security represents a certain set of objects, mechanisms, methods and instruments of protection of national interests, values, freedoms in all spheres of activity of the state and society.

Among all components there are systems of national security, economic security occupies special value as acts as a material basis of ensuring protection of national interests. Interpreting value and essence of economic security in different ways, almost all adhere to a position on its priority in state policy, importance in the conditions of transformational and globalization processes.

Law-enforcement activity in the system of ensuring economic security of the country represents a certain type of the state activity which is carried out by special public authorities of powers and is aimed at law enforcement, law and order, protection of the rights and the interests of the individual, the subject of managing and the state in the economic sphere. Such activity is implemented by application of measures of the state coercion and public influence, in strict accordance with the law and at observance of the procedure (order) established for them, with involvement of guilty persons to legal responsibility. 